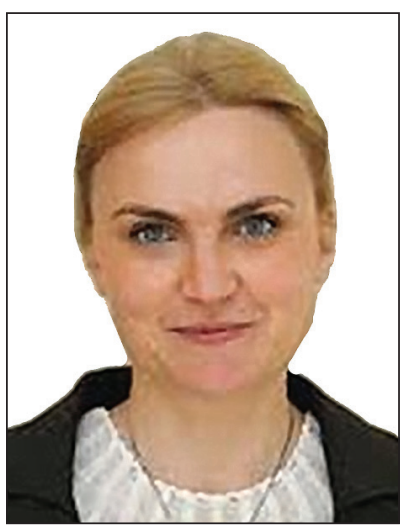

\title{
Pūraitè Aurelija
}

Doctor of Law, Associate Professor,

Vice-Dean for Science,

Academy of Public Security (Lithuania),

Mykolas Romeris University,

Lithuania, Kaunas

e-mail:aurelija.puraite@gmail.com

ORCID 0000-0001-9228-1396

\section{doi: 10.21564/2414-990x.149.201728 \\ UDC 343.37}

\section{ECONOMIC IMPACT OF ORGANISED CRIME TO STATE SECURITY}

Organised crime is changing and becoming increasingly diverse in its methods, group structures and impact on society. This article aims to research, on the one hand, the impact of organized crime on state's economy, on the other hand - to analyse the possible legal and economic measures tackling and preventing organized crime activities. The article contains results of the analysis of international, regional and national legal acts and the secondary analysis of statistical data of European Union agencies and international organizations. The author used a variety of methods: from selection and analysis of primary and secondary sources to descriptive, comparative and synthesis methods. Such analysis required multitudinous, broad and diverse base of empirical data, which were collected from the international, regional, national organizations and agencies, as well as scientific, operational and theoretical reports related to the issue of organised crime and impact of this phenomenon to the state and the society.

Keywords: legal regulation; economic security; organized crime; state security.

Пурайте A., доктор юридичних наук, доцент, заступник декана з питань науки, Академія громадської безпеки, Університет Миколаса Ромеріса, Литовська Республіка, м. Каунас.

e-mail: aurelija.puraite@gmail.com ; ORCID 0000-0001-9228-1396

Економічний вплив організованої злочинності на державну безпеку

Організована злочинність змінюється й стає все більш різноманітною за свойми методами, груповими структурами та впливом на суспільство. Метою публікації є аналіз, з одного боку, впливу організованої злочинності на економіку держави, з іншого - можливих правових й економічних заходів щодо ї подолання та запобігання організованій злочинній діяльності. Стаття містить результати вивчення міжнародних, регіональних та національних правових актів та вторинного аналізу статистичних даних органів Європейського Союзу та міжнародних організаиій. Автор використовував різноманітні методи: від відбору та аналізу первинних та вторинних джерел до описових, порівняльних та методів синтезу. Такий аналіз було здійснено на багатонаціональній різноманітній базі емпіричних даних, які містилися у міжнародних, регіональних, національних організащіях та відомствах, а також результатах наукових, оперативних та теоретичних доповідей, пов'язаних з проблемою організованої злочинності та впливом цього явища на державу та суспільство. 
Ключові слова: правове регулювання; економічна безпека; організована злочинність; державна безпека.

\section{Introduction}

Organized crime (OC) is more than an independent criminal phenomenon. Theoretically, studies show the interdependent correlation between the political, socio-economic, criminal justice and legal domains [2]. The concept of economic security is characterized by its complexity to distinguish accurately and the economic level of the state from the other levels of security - individual, regional and global. Organized crime is changing and becoming increasingly diverse in its methods, group structures and impact on society. It not only menaces peace and human security, but it also undermines economic, social, cultural, political and civil development of societies around the world and violates human rights [20]. OC poses one of the most serious threats to security, stability, democracy and the fundamental civil rights, i.e. values on which the European Union is based. It causes both direct and indirect damage to the state and public security, to human health and welfare, economics, business order and state finances. According to the United Nations, organized crime is among the biggest global challenges to the future of the whole world.

The threat of organized crime is especially notable in the European Union. As the newest research show, 70 per cent of organized crime groups operating on an international level were found to be active in more than three countries. [13]. These groups are taking advantage of the free movement of money, goods, personnel and services across the EU. As a result of the increased sophistication of many organised criminal groups, they can utilise legal gaps and differences between the Member States, exploiting the different regulation in the various systems. Also, it requires states to cooperate in more and more levels seeking to tackle organized crime.

In 2013, Europol reported the presence of at least 3,600 internationally operating organised crime groups (hereinafter - organized crime groups or OCGs) in the EU [14]. As revealed in the SOCTA 2017, there are approximately 5,000 international OCGs currently under investigation in the EU identified. This increase is an indication of shifts in criminal markets and the emergence of smaller groups and individual criminal entrepreneurs in specific criminal activities. These developments also highlight the complex dynamics that shape the serious and organised crime landscape in the EU [13].

Organized crime demonstrates the skills needed to adapt to rapid political and economic change, digitalisation processes. Criminal organizations have increased their scope of actions, enabling a continuous cycle between illegal activities and the reinvestment of capital in the legal economy. Proceeds from illegal activities are reinvested in various types of property and the legal economy, thus criminal organizations can launder the proceeds of crime, differentiate their activities, and discover new sources of financing illegal activities. The negative consequences of this process for society are indeed underestimated: the development of a legitimate economy is distorted, and public resources are misused. Besides, this process is 
accompanied by sophisticated money-laundering mechanisms, which make it difficult to distinguish between legal and illegal economy [48].

It is hard to measure the economic impact of organised crime on a particular state because it is very hard to collect data on their economic activities. Some economic costs (such as environmental damage due to illegal logging, hazardous waste dumping) are not yet included in the big picture of organized crime's impacts [13].

The article aims to research, on the one hand, the impact of organized crime on state's economy, on the other hand - to analyse the possible legal and economic measures tackling and preventing organized crime activities. Even though some scholars state that modern economics "it is economics for itself, in which the economic principles serve its interests" [36, pp. 35-54], from the legal point of view (which is also confirmed by numerous economic studies (for example, [42]), as well as an economic reality, there is an interactive link between economics and legal regulation - one has an impact on another, and vice versa.

\section{Literature review and state of art}

Seeking to achieve the aim of this paper, two main concepts must be determined: the concept of economic security of a particular state, and the concept of organised crime. Basing on methodology what we consider as those two concepts, the findings and interpretation of data gathered may differ.

As classical work of Barry Buzan determines the economy as an influencing factor of policies of the state: «national security cannot be dissociated from the character of the international system, in either its political or its economic dimensions» [3, p. 150]. Links between national security and economic strategies have been analysed by De Souza [10], and the economic security is being acknowledged as a link between national security and social security [33]. Illarionov discussed factors determining the economic security and pointed out that "a country's economic security is understood to mean the combination of economic, political, and legal conditions that provide for the steady production of the maximum quantity of economic resources per capita by the most efficient means in the long run" [22, p. 80]. Luciani debates the difference between a narrow and territorial definition of security, and a broader definition of security encompassing economic interests [19; 28; 31; 44]. In general, it could be concluded that through the development of theoretical concepts towards economic security, bearing in mind the challenges and changing environment of the XXIst century, the tendency of the addition of economic goals to national security objectives could be observed. Recently national as well as international security concept is supplemented with such issues as human rights, economics, the environment, climate change, organised crime, or social injustice, in addition to the traditional concern with security from external military threats. Some scholars proposed such external and internal risk factors of economic security: economic pressure, blockade and other hostile economic external challenges; capital investments for political purposes, the vulnerability of energy system; destabilization of the national currency; economic criminalization; the uncontrolled extent of economic crimes [41]. 
It should be noted, that most authors consider only economic crimes and the dark market as a threat to economic security, however, organised crime has not only direct impact on economics, consequently, on the security of the states, but also indirect influence. Organised crime causes both direct and indirect damage to the state and public security, to human health and welfare, economics, business order and state finances. Unlimited by geographical boundaries (according to the latest data, criminals of more than 180 nationalities were involved in serious and organised crime in the EU), OC uses innovative communication technologies in establishing new partnerships to commit highly profitable crimes. European Union citizens fall victims to serious and organised crime both directly and indirectly.

Many researchers exploring the issue of organised crime observe the aspect of business underlying this phenomenon. Hence we may often come across such descriptions of organised crime as "criminal syndicate", "criminal industry" and similar. P. M. Roth assumes that organised crime is a specific enterprise which uses unlawful economic mechanisms to clean up the market from competitors and which primarily strives for economic objectives rather than power [39, p. 5]. Therefore, the principal area of organised crime is economics since it is enrichment that is the aim of setting up organised crime structures. Organised crime within the economic system surely not only accounts for shadow economy but the entire economy.

Since the year 2000, the United Nations Convention against Transnational Organized Crime has provided an internationally shared definition of an organised criminal group as "a group of three or more persons existing over a period of time acting in concert with the aim of committing crimes for financial or material benefit". This definition was also adopted in the EU's Council Framework Decision 2008/841/ JHA of 24 October 2008 on the fight against organised crime and continues to reflect law enforcement authorities' conceptualisation of organised crime across the world. However, this definition does not adequately describe the complex and flexible nature of modern organised crime networks [13].

Organised crime is a social phenomenon of a new quality level with the underlying key origins - illegal shadow economy or business which causes considerable damage to a state and society. It is this activity (business) that organised crime is associated with through causal, functional and correlation links [9, p. 170]. Following the definition, the characteristics of the phenomenon could be distinguished as follows: continuous criminal activities, a threat to economic and social security of the society, pursuit of material gain and corruption.

\section{Methodology}

OC for understandable reasons is largely unreported and this means that there is little reliable empirical data available. However, it was necessary to make a number of assumptions in order to understand the $\mathrm{OC}$ as an economic threat and to evaluate its impact on the state's security. The article contains results of the analysis of international, regional and national legal acts and the secondary analysis of statistical data of European Union agencies and international organizations. It should be stated the interdisciplinary character of this paper, which corresponds to 
recent wide development of interdisciplinary research methods basically in the field of social sciences (law, economics, sociology, etc.), therefore it is aimed to carry out some «interdisciplinary synthesis» through conclusions of this paper. To achieve the above-mentioned goals, the author will use a variety of methods: from selection and analysis of primary and secondary sources to descriptive, comparative and synthesis methods. Such analysis requires multitudinous, broad and diverse base of empirical data, which could not be collected by authors. Accordingly, the author will use the data and economic indicators of the World Bank publications, NewCronos database of Eurostat, Organization for Security and Co-operation in Europe (OSCE), other international and regional organizations and agencies, also national institutions, such as Statistic Department of Lithuania, as well as scientific, operational and theoretical reports related to the issue of organised crime and impact of this phenomenon to the state and the society.

The most dangerous for European security fields of organised crime is determined by the Council of the EU in 2010 [5]. In 2017 the new priorities were established, in 2018-2021 priority fields are [6; 7]: cybercrime in particular attacks against information systems, child sexual exploitation, and non-cash payment fraud; production, trafficking and distribution of cannabis, cocaine, heroin, new psychoactive substances and synthetic drugs; facilitation of illegal immigration by providing facilitation services to irregular migrants along the main migratory routes crossing the external border of the EU and within the EU, particularly focussing on those whose methods endanger people's lives, those offering their services online and making use of document fraud as part of their business model; organised property crime committed by highly mobile organised crime groups carrying out organised thefts and burglaries across the EU; trafficking in human beings in the EU for all forms of exploitation, including sexual and labour exploitation as well as all forms of child trafficking; illicit trafficking, distribution and use of firearms; environmental crime, more particularly wildlife and illicit waste trafficking; criminal finances and money laundering and facilitate asset recovery; document fraud in the EU, in particular, organised crime groups involved in the production and provision of fraudulent and false documents to other criminals.

Those activities could be analysed from different perspectives: as an issue of human rights, legal, sociological, psychological, economic approaches are also valuable for a better understanding and prevention. The author of the paper took methodological decision to analyse those organised crime activities that affect public and state security the most (rather than are more orientated towards affecting individual persons), those are cybercrime; production, trafficking and distribution of illicit drugs; facilitation of illegal immigration; trafficking in human beings; illicit trafficking, distribution and use of firearms; money laundering. Therefore, for this research, we will analyse economic data of the activities of different organised crime fields, to understand the global impact on economics and possibly to foresee the future trends. There are two main indicators of the economic impact of organised 
crime - the costs related to OC activities, and the benefit generated by OC activities. The authors of Home Office of the United Kingdom report [21] determined, that economic and social cost, or "harm", includes: 1) costs in anticipation of crime include defensive expenditure and precautionary behaviour and are considered to be a cost of crime since they are based on the risk of becoming a victim; 2) costs as a consequence of crime include the value of property stolen or damaged, time costs of replacing property, documents and so on, the emotional and physical impact and reduced quality of life for victims, and reduced effectiveness at work for people affected by crime. In cases where the crime involves violence to the victim, it also includes health costs; 3 ) costs in response to crime are numerous and relate generally to the criminal justice system. This includes costs related to law enforcement and judicial system, legal aid and non-legally-aided defence costs, and costs to the prison and probation services.

It should be taken into consideration, that the best efforts were made to base findings on recorded data from institutional sources, however, all figures and indication of particular numbers should be accepted with caution and considered to be indicative only.

\section{Findings}

Based on the data of the United Nations, the turnover of criminal activities constituted 2 trillion euros in 2009 [49]. As K. Kuchalskis indicates, the drug business alone generates about 24 billion euros per year in the European Union; for comparison, Lithuania's gross domestic product (GDP) was about 36 billion euros in 2016. In the European Union, Europol estimates that the average criminal group of 6-10 members annually reaches a profit of around 1.5 million euros. Illegal profit varies depending on the nature of criminal acts, however, criminal groups engaged in certain types of fraud can generate billions in revenue [27].

Latest data show that OC takes in over $\$ 3$ trillion per year, which is twice all military annual budgets combined. The value of black-market trade in 50 categories from 91 countries at $\$ 1.81$ trillion, not including extortion, racketeering, corruption, and money laundering (due to their overlapping nature). Among their total estimates for those countries are $\$ 339$ billion for illegal drugs; $\$ 200$ billion for counterfeit drugs; $\$ 186$ billion for prostitution; and $\$ 334$ billion for counterfeit products. Cybercrimes are not included, but it is estimated that businesses may lose $\$ 2$ trillion due to cybercrime in 2019 [46].

It is worthwhile to shortly overview the situation of Lithuania as an example of one EU country that faces the direct and indirect impact of organised crime for its economics, social welfare and security. Since 2008 Lithuania's economy has become one of the fastest-growing economies in the EU. From 2013 it rose to eight positions in the World Bank's Doing Business rating smooth in the business start-up category and ranked 11th worldwide [52]. GDP per capita in Lithuania is about 12,428 euros, which is about $75 \%$ of the European Union average [45]. The level of the shadow economy in Lithuania is still high and may reach up to $27 \%$. GDP [23]. According to the results of different studies, the size of the shadow economy in Lithuania in 
$2014 \mathrm{~m}$. accounted for 25 to 27 per cent (according to the research of the Lithuanian Free Market Institute - 25 per cent GDP [30], and according to F. Schneider (cited by Žukauskas, [53, p. 7]) - 27 \%. GDP).

Further, each type of organised crime activity has a different economic impact and the threat to economic security, consequently state security in general, therefore we will analyse those activities through economic figures separately.

\subsection{Cybercrime}

Society as never is being digitized and criminals are using technological innovation adapting those skills to new crime business models. Every year in the world because of cyber-attacks lose $\$ 400$ billion. Other studies show, that the loss is increasing, in 2018 cybercrime costs businesses close to $\$ 600$ billion [37], or 0.8 per cent of global GDP, which is up from a 2014 study that put global losses at about $\$ 445$ billion.

Cybercrime is a low-risk crime that provides high payoffs. The reasons for this growth are as follows: quick adoption of new technologies by cybercriminals; the increased number of new users online (these tend to be from low-income countries with weak cybersecurity); the increased ease of committing cybercrime, with the growth of Cybercrime-as-a-Service; expanding number of cybercrime "centres" that now include Brazil, India, North Korea, and Vietnam); a growing financial sophistication among top-tier cybercriminals that, among other things, makes monetization easier [29].

Table 1. The economic impact of cybercrime

\begin{tabular}{|l|c|c|c|}
\hline $\begin{array}{c}\text { Region } \\
\text { (According to World Bank) }\end{array}$ & $\begin{array}{c}\text { Region GDP } \\
\text { (USD, trillions) }\end{array}$ & $\begin{array}{c}\text { Cybercrime cost } \\
\text { (USD, billions) }\end{array}$ & $\begin{array}{c}\text { Cybercrime Loss } \\
\text { (\% GDP) }\end{array}$ \\
\hline North America & 20.2 & 140 to 175 & 0,69 to $0,87 \%$ \\
\hline Europe and Central Asia & 20.3 & 160 to 180 & 0,79 to $0,89 \%$ \\
\hline East Asia \& the Pacific & 22.5 & 120 to 200 & 0,53 to $0,89 \%$ \\
\hline South Asia & 2.9 & 7 to 15 & 0,25 to $0,52 \%$ \\
\hline $\begin{array}{l}\text { Latin America \& the } \\
\text { Caribbean }\end{array}$ & 5.3 & 15 to 30 & 0,28 to $0,57 \%$ \\
\hline Sub-Saharan Africa & 1.5 & 1 to 3 & 0,07 to $0,20 \%$ \\
\hline MENA & 3.1 & 2 to 5 & 0,06 to $0,16 \%$ \\
\hline World & $\$ 75.8$ & $\$ 445$ to 608 & 0,59 to $0,80 \%$ \\
\hline
\end{tabular}

Source: CSIS, 2014 [4].

It should be noted that according to worldwide cybercrime statistics Lithuania is among 5 countries generating most online fraud (together with Egypt, Ukraine, Indonesia, Yugoslavia) [26, p. 36]. 


\subsection{Production, trafficking and distribution of illegal drugs}

Drug trafficking interferes with legal economic activity in many different ways, and for the present-day especially for the European Union, this is the biggest threat to security: illicit drug trafficking remains the biggest criminal area $-45 \%$ of criminal groups in the EU are involved in drug production and distribution. Each year Europeans spend at least EUR 24 billion on illicit drugs. The cannabis market is the largest, making up about $38 \%$ of the total, followed by heroin ( $28 \%$ ) and cocaine $(24 \%)$. These estimates are based on limited data, with many gaps. Information about the economics of other aspects of the drug market is even more scanty [13]. The hidden nature of the illicit drugs business makes it difficult to estimate the amount of money it generates, but the United Nations Office on Drugs and Crime (UNODC) has estimated that illegal drugs account for about $20 \%$ (17-25\%) of global crime proceeds and are equivalent to about $0.6-0.9 \%$ of global gross domestic product (GDP) [49]. Criminals are investing in new technologies to make the same cost would result in higher drug yields and thus profits. Europol recorded the rise of organised crime groups in Lithuania in heroin and synthetic drug circulation. Lithuania is considered a transit country for the trafficking of illicit substances between Western Europe, Eastern Europe and the Nordic countries, mainly by land [11]. Based on the example of Lithuania another aspect of the economic impact of criminal activities could also be mentioned. As Lithuanian data shows, the economic effect is also in public expenditures tackling any type of crime. As concerns illicit drugs, The National Programme for the Control and Prevention of Use of Drugs, Tobacco and Alcohol 2018-28 was adopted in 2018. In 2017, the labelled expenditure announced in the Action Plan on Drugs, Tobacco and Alcohol was EUR 7.8 million (0.02\% of the gross national product (GDP)). More than half of this expenditure was intended for supply reduction ( $61.7 \%$ of the total); $26.8 \%$ was budgeted for demand reduction and $11.1 \%$ for policy coordination [15].

\subsection{Facilitation of illegal immigration}

There is an unexpressed demand on migration (especially immigration) as an economic and social phenomenon to have some positive impact on the economy of the target country. It's nevertheless true, that from a political point of view the migration trends are usually being associated with the economic, social, security challenges in target countries. Illegal migration usually faces security, regulatory, human rights protection issues, as well as economic, financial and social challenges to destination States [38]. In case migration is legal, it could have a huge positive impact on accepting the state's economy. On the other hand, illegal migration causes substantial negative outcomes. As Europol indicates, more than $90 \%$ of the migrants travelling to the EU used facilitation services. In most cases, these services were offered and provided by criminal groups [8]. Facilitated illegal immigration covers the production and procurement of falsified travel documents or permits obtained under false pretences, the provision of clandestine transportation or other assistance to obtain illegal entry or stay, often connected to several other criminal activities. It is difficult to separate facilitation of illegal migration from other criminal activities - 
human trafficking, migrant smuggling, document fraud. Some criminal groups view migrants as simply one of many commodities to be smuggled, alongside drugs and firearms. Since the smuggling of migrants is a highly profitable illicit activity with a relatively low risk of detection, it is attractive to criminals [50]. It is obvious, that criminal groups gain a huge profit from all illegal activities related to illegal migration. In 2015, criminal networks involved in migrant smuggling are estimated to have had a turnover of between EUR 3-6 billion. These earnings strengthen criminal networks and have a significant negative long-term impact on Europe's economy [16].

\subsection{Trafficking in human beings}

Trafficking in human beings is often linked with other forms of OC such as document fraud, drug trafficking, cybercrime, child pornography, migrant smuggling, benefit fraud. Among other forms of OC trafficking in human beings has been identified as a priority crime threat area in the EU Policy on Organised and Serious International Crime 2014-2017 and the EU Serious and Organised Crime Threat Assessment 2017. Human trafficking earns profits of roughly $\$ 150$ billion a year for traffickers, according to the ILO report from 2014 [24; 25]. The successful human trafficker's business is dynamic, adapting as populations become vulnerable and as areas of demand shift. The revenue from human trafficking is large, an annual estimated average of US\$13,000 per trafficked victim [47, p. 10].

Table 2. Human trafficking profits (in 2014)

\section{Human trafficking profits in total $-\$ 150$ billion}

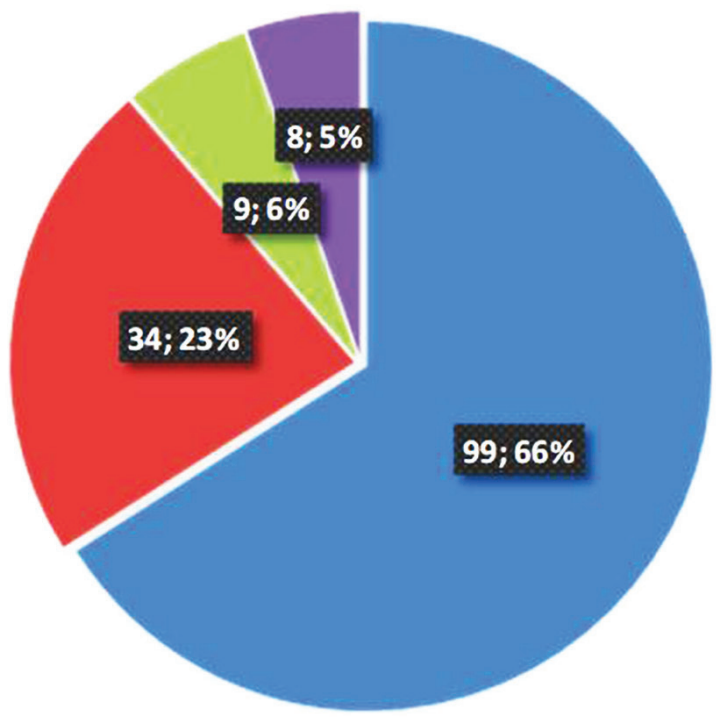

- $\$ 99$ billion commercial sexual exploitation

- $\$ 34$ billion inconstruction, manufacturing, mining and utilities

$=\$ 9$ billion in agriculture, including forestry and fishing

- $\$ 8$ billion saved by private households employing forced labour

Source: author. 
According to other data, annual profits from all forms of trafficking in human beings are estimated at EUR 29.4 billion globally. Following the money throughout the trafficking chain is crucial to turning trafficking in human beings into a "high-risk, low-return" crime. This can be done by intensifying investigations and prosecutions and facilitating proactive financial and intelligence-led investigations, asset recovery, freezing and confiscation of profits [12].

It should be noted, that while only $19 \%$ of victims are trafficked for sex, sexual exploitation earns $66 \%$ of the global profits of human trafficking. The average annual profits generated by each woman in forced sexual servitude $(\$ 100,000)$ is estimated to be six times more than the average profits generated by each trafficking victim worldwide $(\$ 21,800)$, according to the Organization for Security and Cooperation in Europe [35].

OSCE studies show that sexual exploitation can yield a return on investment ranging from $100 \%$ to $1,000 \%$, while an enslaved labourer can produce more than $50 \%$ profit even in less profitable markets (e.g., agricultural labour in India). A few specific examples could be mention, for example, in the Netherlands, investigators were able to calculate the profit generated by two sex traffickers from several victims. One trafficker earned $\$ 18,148$ per month from four victims (for a total of $\$ 127,036$ ) while the second trafficker earned $\$ 295,786$ in the 14 months that three women were sexually exploited according to the OSCE [35]. While sexual exploitation generates profits, forced labour saves costs. In one case, Chinese kitchen workers were paid $\$ 808$ for a 78 -hour workweek in Germany. According to German law, a cook was entitled to earn $\$ 2,558$ for a 39-hour workweek according to the OSCE [35].

\subsection{Illicit trafficking, distribution and use of firearms}

Scientists very precisely observed that "like drug trafficking is a catalyst criminal activity worldwide due to the high level of profits it produces, firearms' trafficking is a pivotal criminal activity worldwide due to the high demand in several criminal hotspots" [40, p. 10]. The illicit manufacturing, acquisition and trafficking of firearms also function as a market commonly known as the "illicit global market". Whereas older forms of firearms trafficking were to a large extent dominated by geo-political considerations, researchers have argued in the recent past that economic profit has increasingly become the chief supplier motivation [32]. The trafficking of firearms is different from most other forms of organized crime activity in that it is a durable, rather than a consumable, good. It is difficult to assess the scale of illicit firearms trafficking because of its nature. When evaluating the number of illegal firearms used and possible profit that organised crime groups gain from this activity, some indicators are taken into consideration: a broad indicator based on the number of unregistered firearms, and a narrower measure based on firearms seizures; the number of firearms-related homicides; illegal firearms used during violent incidents; the extent to which illicit firearms trafficking supports activities such as human trafficking and drugs smuggling. According to the UNODC, the illegal firearms trade generates between $€ 125$ million to $€ 236$ million per year globally, which represents between 10 to $20 \%$ of the total trade in legal firearms [49]. The surveys 
estimate that there are some 875 million small arms and light weapons in circulation worldwide. Between 530,000 and 580,000 are produced annually, either under licence or as unlicensed copies, by an estimated 1,249 companies in more than 90 countries. Experts state that the international small arms trade is worth an estimated US $\$ 8.5$ billion with a further US\$2 billion spent on illicit weapons. The largest exporters of licit weapons are Russia, the United States, China, Brazil, Italy, Germany, France, Belgium and the United Kingdom [43]. Another estimate of the value of the illicit firearms trade is provided by Geopolitical Monitor [18] estimates the illicit market to be worth around US\$ 1 billion.

\subsection{Money laundering}

It was estimated that in 2009 from crime generated $3.6 \%$ of global GDP and $2.7 \%$ (or $\$ 1.6$ trillion) is involved in money laundering. Such calculations also coincided with the International Monetary Fund calculations according to which money laundering income in the world could account for $2-5 \%$ of the value of world GDP [17]. However, it is difficult to determine the precise economic impact of illegal activities, as the income of organised crime activities is being reinvested and legalised further performing multiple actions. Also, it should be noted, that money laundering itself is a serious crime, and most often it comes as a consequence of other activities of organised crime groups. A simple example of a combination of a few criminal activities could be presented: for example, a person received 200 thousand euros in illicit drug trafficking, which were put into the bank account of the tax haven country to open an online gambling account. After short gambling remaining unlost money are transferred to a real bank account as a «win» money while avoiding taxation, which is not applied for winnings in some countries [34]. Also, it should be noted, that recently money laundering became a relevant part of organised crime activities. Most often countries or sectors with weak anti-money laundering options are selected to commit the crime. A booming economy with fast-developing financial centres and weak oversight by competent authorities are actively used perpetrating money laundering by criminals. Speaking about economic security, the reports and statistical data of money laundering criminal activities are the most precise and can be at least indicated by some particular figures. Money laundering allows criminal groups to invest in proceeds from illegal activities into the legal or illegal economy. It is said that money laundering is the lifeblood of organized crime and money laundering allows the illicit ventures of the criminal organized groups and individuals to continue [1, p. 445].

Speaking generally, it is obvious that organised crime is a big business that generates huge turnover and gains substantial profit. While it is recognised that international crime acts globally, the impact is mostly felt locally, therefore everybody is under influence. The effect of organised crime is not only on tax exemption nature of is activities but it also affects the structure of public spendings in each country more must be spent to law enforcement and security assurance, not to mention an increased level of criminality and insecurity of the society. It threatens peace and human security, leads to human rights being violated and undermines the economic, 
social, cultural, political and civil development of societies around the world [51]. Those are additional latent costs of organised crime, that raises this phenomenon to a higher level than the only economical threat to society and state.

Conclusion. It is obvious that organised crime is evolving as all factors that influence society, also have an impact on development and changes of organised crime. This phenomenon becomes more and more complex, flexible, adaptive, multidimensional, it adopts new forms and ways of acting. Bearing in mind the profit that organised crime generates from its illegal activities, also the direct and indirect impact on worlds economics, it is clear that organised crime affects much more than only economics of the states, it also has interconnections with other global, regional and national threats (which might vary from country to country depending on different factors). During past decades the scope of organised crime activities increased dramatically, with a huge impact on modern technologies. It must be mentioned, that until the $21^{\text {st }}$ century there was almost no scientific research in the field. Only past decades it became clear that tackling organized crime is important to use the newest research possibilities, involving all possible innovative means of response to that unprecedented threat. It is difficult to evaluate economic factors of organised crime, as they constitute a complex system of different indicators, therefore research in this field is essential, as only understanding the scale and impact of organized crime to society, political stability, human rights may raise the policy and decisions taken to another dimension.

\section{References}

1. Aluko, A., Bagheri, M. (2012). The impact of money laundering on economic and financial stability and political development in developing countries. Journal of Money Laundering Control, vol. 15, 4, 442-457. URL: https://doi.org/10.1108/13685201211266024.

2. Buscaglia, E. \& Van Dijk, J. (2003) Controlling organized crime and corruption in the public sector». Forum on Crime and Society, vol. 3, 1/2. URL: www.unodc.org/pdf/crime/forum/forum3_ Art1.pdf.

3. Buzan, B. (2007). People, States and Fear: An Agenda for International Security Studies in the Post-Cold War Era. $2^{\text {nd }}$ ed. Hemel Hempstead: Harvester Wheatsheaf.

4. Centre for Strategic \& International Studies (2018). Global Development Forum. URL: https:// www.csis.org/events/2018-global-development-forum.

5. Council of the European Union. (2010). Council conclusions on the creation and implementation of an EU policy cycle for organised and serious international crime (doc.15358/10).

6. Council of the European Union. (2018). Council Conclusions on setting the EU's priorities for the fight against organised and serious international crime between 2018 and 2021 (doc 9450/17).

7. Council of the European Union. (2018). Council Conclusions on the continuation of the EU Policy Cycle for the organised and serious international crime for the period 2018-2021 (doc 7704/17).

8. Council of the European Union. (2017). The EU Policy Cycle to Tackle Organised and Serious International Crime. EMPACT. URL: http://www.consilium.europa.eu/en/policies/eu-fightagainst-organised-crime-2018-2021/.

9. Dapšys, A. (1998). Organized crime and corruption: prevention and control systems Prerequisites and Perspectives of Creation in Lithuania. Legal Problems, 3-4 (21-22), 166-185.

10. DeSouza, P. (2000). Economic strategy and national security: A next-generation approach. Westview Press. 
11. European Monitoring Centre for Drugs and Drug Addiction. (2016). EU Drug Markets Report. In-depth Analysis. 2016, Europol. URL: http://www.emcdda.europa.eu/system/files/publications/2373/TD0216072ENN.PDF.

12. European Commission. (2015). Communication from The Commission To The European Parliament and The Council. Reporting on the follow-up to the EU Strategy towards the Eradication of trafficking in human beings and identifying further concrete actions. Brussels, 04.12.2017. COM(2017) 728 final.

13. Europol. (2017). European Union Serious and Organised Crime Threat Assessment. 2017, Crime in the Age of Technology, Europol. URL: https://www.europol.europa.eu/activities-services/mainreports/european-union-serious-and-organised-crime-threat-assessment-2017.

14. Europol. (2013). EU Serious and Organised Crime Threat Assessment (SOCTA 2013). Europol, Published at 19 March 2013. URL: https://www.europol.europa.eu/activities-services/main-reports/ eu-serious-and-organised-crime-threat-assessment-socta-2013.

15. European Monitoring Centre for Drugs and Drug Addiction (2019). Lithuania. Country Drug Report 2019. URL: http://www.emcdda.europa.eu/countries/drug-reports/2019/lithuania/drugmarkets_en.

16. Europol. (2019). Facilitation of illegal migration. URL: https://www.europol.europa.eu/crimeareas-and-trends/crime-areas/facilitation-of-illegal-immigration.

17. FATF (The Financial Action Task Force) (2018). Professional Money Laundering. URL: http://www.fatf-gafi.org/media/fatf/documents/Professional-Money-Laundering.pdf.

18. Geopolitical Monitor. (2011). The Illicit Trade Of Small Arms. URL: http://www. geopoliticalmonitor.com/the-illicit-trade-ofsmall-arms-4273/.

19. Glenn, J.C. \& Florescu, E. (2017). State of the Future. 19.0. The Millennium Project publishing.

20. Home Office. (2011). Local to Global: Reducing the Risk from Organised Crime. URL: www. homeoffice.gov.uk/crime/ organised-crime-strategy/.

21. Home Office. (2008). Organised crime: revenues economic and social costs, and assets available for seizure. Published 4 August 2008. URL: https://assets.publishing.service.gov.uk/government/ uploads/system/uploads/attachment_data/file/251075/6167.pdf.

22. Illarionov, A. (1999). The Criteria of Economic Security. Problems of Economic Transition, vol. 41, issue 12, 63-92. The Institute for Economic Analysis. Published online: 8 Dec 2014. URL: https:// doi.org/10.2753/PET1061-1991411263.

23. Information Technology and Communications Department under the Ministry of Interior of the Republic of Lithuania. (2017). Crime Statistics. URL: https://www.ird.lt/en/internationalcooperation-1/crime-statistics-1.

24. International Labour Organisation. (2014). Profits and Poverty: The economics of forced labour. URL: https://www.ilo.org/wcmsp5/groups/public/---ed_norm/---declaration/documents/ publication/wcms_243391.pdf.

25. International Labour Organisation. (2017). Global Estimates of Modern Slavery. Forced Labour and Forced Marriage. URL: https://www.ilo.org/wcmsp5/groups/public/@dgreports/@dcomm/ documents/publication/wcms_575479.pdf.

26. Kshetri, N. (2006). The simple economics of cybercrimes. IEEE Security and Privacy Magazine. February 2006. doi: 10.1109/MSP.2006.27.

27. Kuchalskis, K. (2018). Organised Crime: New Challenges and Response Addressing Them. Lithuanian Annual Strategic Review, 2017-2018, vol. 16. DOI: 10.2478/lasr-2018-0008.

28. Levi, M., Reuter, P., Gundur, R.V. (2013). The Economic, Financial EF Social Impacts of Organised Crime in the EU. European Parliament. doi: 10.2861/36979.

29. Lewis, J.A. (2018). Economic Impact of Cybercrime. Centre for Strategic \& International Studies. URL: https://www.csis.org/analysis/economic-impact-cybercrime.

30. Lithuanian Free Market Institute. (2015). Shadow Economy. URL: https://en.llri.lt/dedicated/ shadow-economy.

31. Luciani, G. (1988). The Economic Content of Security. Journal of Public Policy, vol. 8, issue 2, April 1988, 151-173. DOI: https://doi.org/10.1017/S0143814X00006966. 
32. Naylor, R.T. (1994). Loose Cannons: Covert Commerce and Underground Finance in the Modern Arms Black Market. Crime, Law and Social Change, vol. 22, issue 1, 1-57.

33. Neocleous, M. (2006). From Social to National Security: On the Fabrication of Economic Order. Politics and History Section, vol. 37, issue 3, 363-384. Issue published: September 1, 2006. Brunel University, UK. URL: https://doi.org/10.1177/0967010606069061.

34. OECD. (2019). Money Laundering and Terrorist Financing Awareness Handbook for Tax Examiners and Tax Auditors, OECD, Paris. URL: www.oecd.org/tax/crime/money-laundering-andterrorist-financing-awareness-handbook-for-tax-examiners-and-taxauditors.pdf.

35. OSCE. (2010). Analysing the Business Model of Trafficking in Human Beings To Better Prevent the Crime. URL: https://www.osce.org/secretariat/69028?download=true.

36. Osipov. J. (2011). «Alternative Interpretation Of Economics» In Montenegrin Journal of Economics, vol. 7 (2), 35-54. URL: http://repec.mnje.com/mje/2011/v07-n02/mje_2011_v07n02-a11.html.

37. Paganini, P. (2019). Cybercrime and the Underground Market. URL: https://resources. infosecinstitute.com/cybercrime-and-the-underground-market/\#gref.

38. Pūraitè, A., Greičius, S., Pranevičienè, B., Seniutienè, D. (2017). Managing State Border in the Context of Migration Crisis in Europe: Lithuanian Case. Montenegrin Journal of Economics, vol. 13, 3 , 31-42. DOI: 10.14254/1800-5845/2017.13-3.3.

39. Roth, P.M. (2017). Global Organized Crime. A $21^{\text {st }}$ Century Approach. $2^{\text {nd }}$ ed. London: Routledge.

40. Salcedo-Albaran, E. \& Santos Cubides, D. (2017). Salcedo-Albaron, Eduardo and Diana Santos Cubides. Firearms Trafficking: Mexico-United States Border. The Global Observatory of Transnational Criminal Networks, Research Paper, 16, Bogotб: Vortex Foundation.

41. Simanavičienė, Ž., Stankevičius, A. (2015). Economic security and national competitiveness. Public Security and Public Order, 15. URL: https://repository.mruni.eu/handle/007/15011.

42. Simanavičienè, Ž., Simanavičius, A., Pocius, V. (2017). Economic security and national competitiveness. Public Security and Sustainable Development: Current Issues and Problems in Public Security. URL: https://hdl.handle.net/20.500.12259/91507.

43. Small Arms Survey. Weapons and the World. (2015). Cambridge University Press.

44. Sperling, J. \& Kirchner, E. (1998). Economic security and the problem of cooperation in post-Cold War Europe. Review of International Studies, 24, 221-237. doi: https://doi.org/10.1017/ S0260210598002216.

45. Lithuanian Statistical Department under the Government of the Republic of Lithuania. (2018). Main figures. URL: https://osp.stat.gov.lt/.

46. The Millennium Project. (2019). The American Council for the United Nations University. URL: http://www.millennium-project.org/projects/challenges/.

47. Wheaton E. M., Schauer, E.J., Galli, T.V. (2010). Economics of Human Trafficking. International Migration, vol. 48 (4). doi: 10.1111/j.1468-2435.2009.00592.

48. United Nations Interregional Crime and Justice Research Institute. (2014). The impact of organized crime on the legal economy: identifying strategies to disrupt criminal investment in key sectors. URL: http://www.unicri.it/news/article/organized_crime_.

49. United Nations Office on Drugs and Crime. (2011). Estimating Illicit Financial Flows Resulting from Drug Trafficking and Other Transnational Organised Crime, Research report. URL: https://www. unodc.org/documents/data-and-analysis/Studies/Illicit_financial_flows_2011_web.pdf.

50. United Nations Office on Drugs and Crime. (2010). The Globalization of Crime: A Transnational Organized Crime Threat Assessment, United Nations publication, Sales No. E.10.IV.6. URL: www. unodc.org/documents/data-and-analysis/tocta/TOCTA_Report_2010_low_res.pdf.

51. United Nations Office on Drugs and Crime. (2009). Transnational Organized Crime - The Globalized Illegal Economy. URL: https://www.unodc.org/documents/toc/factsheets/TOC12_fs_ general_EN_HIRES.pdf.

52. World Bank. (2019). Ease of Doing Business rankings. URL: https://www.doingbusiness.org/ en/rankings. 
53. Žukauskas, V. (Ed.). (2013). Lithuanian Shadow Economy. Periodical First half-year report 2013, 2. URL: http://files.lrinka.lt/LSE2013_2/LSE_EN.pdf.

Пурайтэ A., доктор юридических наук, доцент, заместитель декана по науке, Академия общественной безопасности, Университет Миколаса Ромериса, Литовская Республика, г. Каунас.

e-mail: aurelija.puraite@gmail.com ; ORCID 0000-0001-9228-1396

Экономическое влияние организованной преступности на государственную безопасность

Организованная преступность меняется и становится все более разнообразной по своим методам, групповым структурам и влиянием на общество. Целью публикащии является исследование, с одной стороны, влияния организованной преступности на экономику государства, $c$ другой - анализ возможных правовых и экономических мер по преодолению и предотвращению такой деятельности. Статья содержит результаты анализа международных, региональных и национальных правовых актов и вторичного анализа статистических данных органов Европейского Союза и международньх организаций. Автор использовал различные методы: от отбора и анализа первичных и вторичных источников до описательных, сравнительных и методов синтеза. Такой анализ проведен на многонациональной, разнообразной базе эмпирических данньх, полученной от международных, региональных, нащиональных организащий и ведомств, а также с научных, оперативных и теоретических докладов, связанных с проблемой организованной преступности и влиянием этого явления на государство и общество.

Ключевые слова: правовое регулирование; экономическая безопасность; организованная преступность; государственная безопасность.

Рекомендоване цитування: Pūraitė A. Economic impact of organised crime to state security. Проблеми законності. 2020. Вип. 149. С. 185-199. doi: https://doi.org/10.21564/2414-990x. 149.201728 .

Suggested Citation: Pūraitè, A. (2020). Economic impact of organised crime to state security. Problemy zakonnosti - Problems of Legality, issue 149, 185-199. doi: https://doi. org/10.21564/2414-990x.149.201728.

Надійшла до редколегії 28.04.2020 p. 